\title{
Noninvasive Positive Pressure Ventilation
}

\author{
多田羅勝義 \\ (国立療養所徳島病院小児科)
}

Key words : Noninvasive Positive Pressure Ventilation, Nasal Pressure support Ventilation, BiPAP, Home Mechanical Ventilation, 鼻マスク

\section{1.はじめに}

従来，長期人工呼吸に扔いては気管切開が必 須と言われていた。ところが近年気管切開によ らない非侵襲的人工呼吸，特に Noninvasive Positive Pressure Ventilation (以下 NPPV) が注目されている。非侵襲的人工呼吸には他に 体外式人工呼吸器，二ューモベルト（日本では 認可されていない)などを用いる方法があるが, 現在主としておこなおれているのはNPPVで ある。

NPPV は気管切開法に比べ患者が非常に受 け入れやすい。筆者の経験でも，患者・家族が 気管切開を実施する決心がつかず，人工呼吸開 始の時期が遅れてしまった症例が少なくない。 また NPPVは，現在急速にその数が増加して いる在宅人工呼吸 (Home Mechanical Ventilation，以下 HMV）でもその占める割合が大き い。このように様々な場面で注目をあびている NPPV であるが，その導入，管理には多くの解 決すべき問題がある。例えばNPPVによる人 工呼吸では換気の効果が非常に不安定である。 さらにNPPVでは気管切開法のように切開し た時点から直ちに予定した人工呼吸による効果 が得られるわけではない。呼吸管理の面からも NPPV なるがゆえの特殊な問題点も多い。また 同方法は現在のところ臨床現場で広く浸透して いるとは言い難い。地元の病院で気管切開によ る人工呼吸しか方法がないと言われ筆者のとこ ろに相談に来た筋ジストロフィー患者も少なく ない。

この総説ではNPPVの歴史を簡単に紹介
し，その実施における問題点を提示しその具体 的解決策を述べる。

\section{NPPV の歴史 ${ }^{1,2)}$, 現状}

従来，神経筋疾患などの長期に人工呼吸を必 要とする症例に対しては体外式人工呼吸器によ る陰圧式換気法あるいは気管切開による陽圧式 換気法が用いられてきた。陰圧式換気法は筆者 の施設でもまだ使用されているが，その換気効

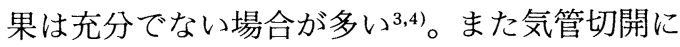
よる陽圧式換気方法は換気効果は良好である が，発声の問題，気道出血の問題など新たな問 題が発生し，さらに患者，家族が受け入れるに も抵抗がある場合がある。

鼻マスクは1981年に Sullivan 等 ${ }^{5}$ が閉塞性 睡眠時無呼吸症候群の治療に nasal CPAP の かたちで導入，また1980年代後半に神経筋疾患 あるいは脊柱後側弯症などの胸郭性拘束性換気 障害に対して鼻マスクを用いた NPPV の有用 性の報告 ${ }^{6 \sim 9)}$ が相次いだ。さらに, 最近では慢性 呼吸不全だけでなく急性呼吸不全例にも応用さ れつつある。Respiratory Care 誌の1997年 4 月 号はNPPV の特集号であったが，その中で各 種疾患における NPPV の有効性についてまと めている。はっきり「有効」とされているのは 成人の神経筋疾患, 胸壁疾患などが挙げられて いるが，小児例については過去にコントロール 対象のない症例報告しかないということで,「有 効かもしれない」という評価であった。同じく 小児例としては肺実質疾患（例えば低酸素血症 を伴う肺炎), 胸壁疾患, Cystic fibrosis が有効 な可能性のある疾患として挙げられている。ま 
た「神経筋疾患の呼吸管理」には小児例への適 応が急速に広まっているとし，年齢に関しては 7 力月以降であれば充分可能と記載されてい る。筆者も人工呼吸の際にはまず NPPVを選 択肢として検討すべきと考えている。一方，同 じ神経筋疾患でもその疾患により NPPV 実施 の際の問題点は相当違ってくる事も経験してい る。ここに記した筆者の経験は主として筋ジス トロフィーへの NPPV 導入をもとにしたもの であるが，他疾患への導入に際しては既成概念 にとらわれず常に詳細な観察，評価のもとにお こなっていくべきであろう。

また現状では用語，略語についても混乱して いる。ここでは Noninvasive Positive Pressure Ventilationの略としてNPPV を用いたが，こ の略はNIPPVとする場合もある。一方 NIPPV は Nasal Intermittent Positive Pressure Ventilationの略とすることもある。最近 注目の BiPAP は，日本では Bilevel Positive Airway Pressure Ventilationの略として換気 モードを指すことも多いが，そもそもは Respironics 社の BiPAP Ventilatory Suport System という装置の固有名詞として登録されている。 この BiPAP は睡眠時無呼吸に対する治療法で ある nasal CPAPを換気不全にも対応するよ うに改良したものである。ところがその簡便さ， 優れた換気効果により近年慢性呼吸不全患者あ るいは急性呼吸不全患者に対しても使用される ようになってきた。な扢この総説では Nasal Pressure Support Ventilation (以下 NPSV) とした。このような用語の混乱は日本だけの問 題ではないようだが，くわしくは前述の Respiratory Care 誌を参照していただきたい。

\section{NPPV の実際一人工呼吸器一}

\section{1. 使用する人工呼吸器}

一般に NPPV にはガス供給配管のいらない ポータブル型人工呼吸器を用いる。ポータブル 型人工呼吸器使用の場合は, 人工呼吸の既成概 念では思いもつかない発想もでてくる（図 1)。 NPPV は歴史的に見てもHMVを強く意識し ている方法であるからポータブルという条件は 重要である。さらにNPPVの回路は厳密に言 うと閉鎖回路ではない。したがってガス配管を

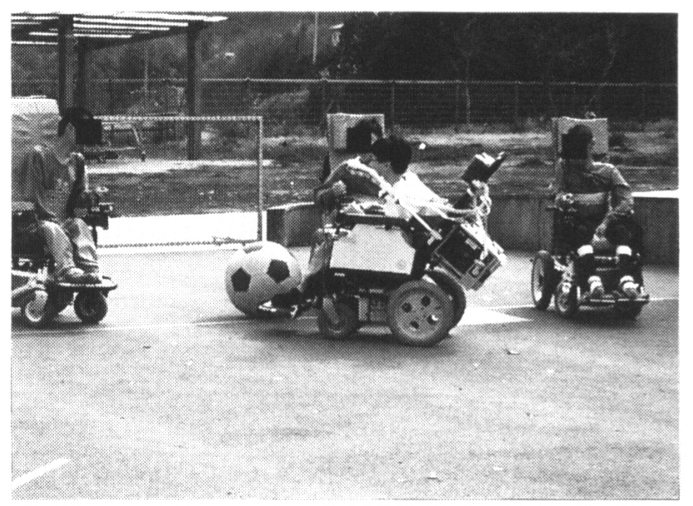

図 1 人工呼吸を抢こないながらの電動車椅子サッ カ一

ここでは小工呼吸器と患者をつなぐインター フェイスとしてマウスピースを使用してい る。NPPVではしばしば従来の人工呼吸の概 念からはとても考えられないような事態がお こる。

必要とするようないわゆる高級人工呼吸器では 低圧アラームが頻回になり実際には使用が困難 である。

ポータブル型人工呼吸器には従量式のものと NPSV 装置がある。現在日本で流通している主 な機種を表に示した。両者にはそれぞれ利点欠 点があり,症例によって使い分ける必要がある。

従量式人工呼吸器を使った NPPVの場合, 期待する換気効果を得るためにはある程度患者 の協力が必要である。症例によっては効果が得 られるまでに 1 力月近くかかることもめずらし くない。また対象が年少児の場合，知的障害の ある場合には導入が困難なこともある。内科領 域でも老人で祸呆のある場合には困難という。 このような時はNPSVの方が導入しやすい。 筆者も福山型筋ジストロフィー患者, 軽度の知 的障害を有する 9 歳のデュシャンヌ型筋ジスト ロフィー患者にNPSVを導入し良好な結果を 得た経験がある10)。年少児への従量式人工呼吸 器を使用したNPPVの導入については今後の 検討に待たなければならないところが多い。

同じく従量式人工呼吸器を使った NPPVで は睡眠時の口腔などからのエアーリークのため 充分な効果を得られないことがある。フルフエ イスマスク，チンストラップの使用などによる 対策にも限界がある。このような場合エアーリ 
ークによる補正を自動的に抗こなうNPSVで 劇的に改善することがある11)

NPSV の欠点の 1 つは電源の問題である。内 臓バッテリーを備えた機種はない。外部バッテ リ一使用にも制限がある場合が多い。これは HMVの場合には重要な問題である。また当院 で実施しているような電動車椅子に人工呼吸器 を搭載して使用するということも難しい。一方, 同装置は最近小児の人工呼吸器としても注目さ れている ${ }^{12)}$ 。筆者も前述の筋ジストロフィー児 のほか, 10歳の Spheroid Myopathy の患児に 導入し良好な結果を得ている。しかし年少児の 場合には呼気ガスの再呼吸が問題となる可能性 があり, 呼気弁をつけるなどの工夫が必要であ る。

2. 換気モード

(1) 従量式人工呼吸器

従量式の場合どの機種でも換気モードとして control モード, assist/control モード, SIMV モードが用意されている。神経筋疾患患者では SIMVモードでは自発呼吸努力が大きくなる こともあり，あまり好まれない。また意外なこ とに control モードでも容易に人工呼吸器に同 期できることが多い。米国では, 小児神経疾患 では約半数が assist/control モード, control モ 一ドも $20 \%$ に及ぶとの報告もある（第17回日本 人工呼吸学会での Haddock, H.D. 氏の講演よ り，1995)。また Simonds ${ }^{13)} は$, assist/control モードを推奨している報告が多いとしている。 筆者も現在のところ全例 assist/control モード を用いている。assist/control モードではいわ ゆる「2 度吸い/2 度呼吸」を扢こし気道内圧 上昇のアラームが鳴ることがある。例えば一回 換気量が $300 \mathrm{ml}$ に設定されている場合, 患者が $500 \mathrm{ml}$ 吸気しようとしても $300 \mathrm{ml}$ しか流れな い。そこで患者はわずかに呼気しただけで再度 吸気を開始する。しかしこの吸気にも $300 \mathrm{ml}$ が 供給され，今度は過剩供給となる現象である。 これは導入初期によくおこり, 患者はパニック になりやすいが，充分説明してやればすぐに慣 れておこさなくなる。

ごく最近ポータブル型従量式人工呼吸器で Pressure Support Ventilation が可能な機種が 発売された。しかし筆者には使用経験がなくこ
こでは触れなかった。

(2) NPSV

Respironics 社の BiPAPでは S (spontaneous), S/T (spontaneous/Timed), T(Timed) といったモードの選択が可能である（BiPAP S はS モードのみ)。これらはそれぞれ assist モ ード, assist/control モード, control モードに 対応すると考えてよい。O'NYX, PB335でもそ れぞれ呼び方は違うが同様のモードの選択が可 能である。しかしいずれにせよ人工呼吸器とし て用いるには, 自発呼吸トリガーに頼らないバ ックアップ換気のための設定ができることが重 要となる。

\section{3. 一回換気量}

一回換気量はあくまで呼吸器が送り出す量で あることを忘れてはいけない。抻管, 気管切開 例では呼吸器の送気量がほぼ換気量となる。と ころがNPPVでは一回換気量が挿管時の 2 倍 必要といわれている ${ }^{14)}$ 。筆者の経験でも NPPV では実際の換気量が設定量の $1 / 2,2 / 3$ といった ことがめずらしくない。そこで一般的に設定は $15 \sim 20 \mathrm{ml} / \mathrm{kg}$ とする ${ }^{15)}$ 。この差は特に導入初期 に大きい。また睡眠時に大きくなる。一方，慣 れてくるとこの差は小さくなり, 送気量の $80 \%$ 程度で落ち着くことが多い。いずれにせよ流量 計での換気量の確認が欠かせない。

\section{4. 呼吸回数}

基本的には血液ガス分析などで換気状態を確 認して決定すべきであるが，神経筋疾患患者の 人工呼吸は当初睡眠時のみ実施することが多 い。したがって血液ガス分析での確認は困難で ある。そこでとりあえずは $10 〜 15 / \mathrm{min}$ 程度の設 定で始める。モードは assist/control であるか ら不足分は自発呼吸トリガーでというわけであ る。他の報告でも $15 / \mathrm{min}$ 程度というものが多 い。一方，神経筋疾患では覚醒時には楽に自発 呼吸トリガーがかかっていても睡眠時にはかか りづらい場合もあるのでバックアップのための 呼吸数はあまり自発呼吸を頼りにせず設定して おく方がよい。またこのような症例では覚醒時 には逆にできるだけバックアップ呼吸回数を減 らしておいた方が発声, 飲食などが容易におこ なえる。 
5 . 流量, I : E 比

いずれも吸気にどのような圧曲線を描かせる かの設定である。筋ジストロフィーをはじめと した筋疾患患者ではゆっくりとした立ち上がり が好まれることが多い。この傾向は特に導入時 に強い。

6.アラーム

アラーム音によりかえって睡眠が妨げられる ため, 筆者は低圧アラームを $2 \mathrm{cmH}_{2} \mathrm{O}$ と最低 に設定している。しかし特に24時間使用の患者 では回路のはずれ（圧モニターのためのチュー ブ，呼気弁開閉のためのチューブなどがはずれ やすい）に対する低圧アラームは重要である。 高圧アラームは40〜 $50 \mathrm{cmH}_{2} \mathrm{O}$ とすることが多 い。 2 度吸い/2 度呼吸など患者と呼吸器が合 わない時アラームが作動するが，慣れればこの 種の原因の高圧アラームは減少する。したがっ て安定期に入ってからの高圧アラームでは常に 喀痰などによる気道狭窄を念頭におくべきであ る。

7.トリガー感度

トリガー感度の問題は非常に重要である。感 度の悪い場合には呼吸仕事量が自発呼吸時と変 わらないという報告もあり，何のために人工呼 吸をしているのかわからなくなる。従量式人工
呼吸器の場合压トリガーであるが，現状では必 ずしも満足のいくものとは言えない。患者の自 発呼吸は弱く，トリガー感度はできるだけ低く しておかなければならないが，逆に低すぎると 発声などによる微妙な圧変化にも応答してしま い, 予定外の吸気に慌ててしまうことがよくあ る。またポータブル型従量式人工呼吸器ではト リガーがかかってからのガスの送り出しにかか る時間（time lag）もまだまだ大きい。一方， NPSVではフロートリガーを主体としており， 患者にとってより受け入れやすくなっている。

8.タイマー

人工呼吸器のタイマーは本来定期検査の目安 とするためのものである。しかしこの確認は人 工呼吸器使用患者の病態の変化確認のためにも 役に立つ。これを定期的に記録することにより， 患者の一日当たりの人工呼吸器使用時間を知る ことができる。例えば当初睡眠時のみ使用の筋 ジストロフィー患者が次第に覚醒時にも必要と なり，一日当たりの使用時間の延長を確認する ことにより呼吸不全の進行がわかる。ほとんど の機種に専用メータが装備されているが，LP6 plusでは専用のメータはなく圧メータに表示 された数字を200倍して求める。またPB335に はまったく装備されていない。

表 ポータブル型人工呼吸器 (呼吸補助装置)

\begin{tabular}{|c|c|c|c|}
\hline 機 種 & 国内代理店 & メ - 力 - & 寸 \\
\hline Companion2801 & $\begin{array}{l}\text { ネルコアピューリタン } \\
\text { ベネットジャパン }\end{array}$ & Nellcor Puritan Bennet & $\begin{array}{l}\text { 手動のsigh は呼吸訓練に利用 } \\
\text { できる }\end{array}$ \\
\hline Companion335 & $\begin{array}{l}\text { ネルコアピューリタン } \\
\text { ベネットジャパン }\end{array}$ & Nellcor Puritan Bennet & $\begin{array}{l}\text { 操作が簡単 } \\
\text { 外部バッテリーは使えない }\end{array}$ \\
\hline LP6 plus & IMI & Nellcor Puritan Bennet & \\
\hline O'NYX & IMI & Nellcor Puritan Bennet & $\begin{array}{l}\text { コンパクトにまとまっているが, } \\
\text { ユーザーインターフェイスが悪い }\end{array}$ \\
\hline PLV-100 & フジアールシー & Lifecare & \\
\hline $\begin{array}{l}\text { BiPAP STD, } \\
\text { STD30 }\end{array}$ & フジアールシー & Respironics & $\begin{array}{l}\text { 操作が簡単 } \\
\text { 压モニター等はオプション }\end{array}$ \\
\hline BEAR33 & コーケンメディカル & Bear Medical System & \\
\hline
\end{tabular}

Companion2801, LP6 plus, PLV-100, BEAR33についてはほとんどの使用上の差はない。 ここに挙げた機種は筆者の使用経験があるものとしたため, 一部掲載されていない機種もある。 従量式はいずれも最低一回換気量が $0.05 \sim 0.1 \mathrm{~L}$ 。 


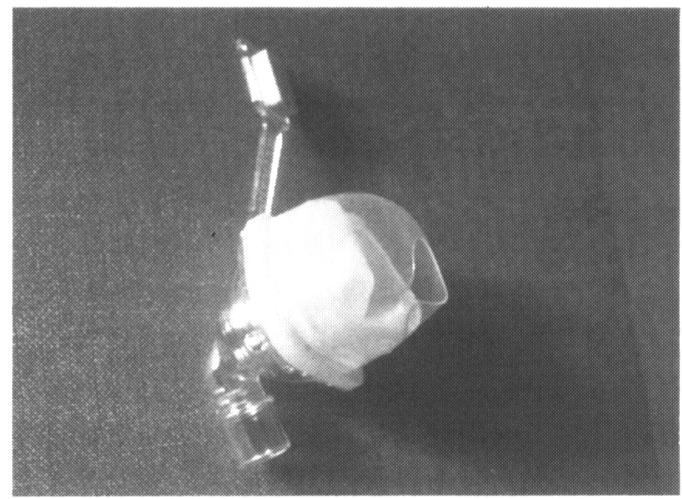

A

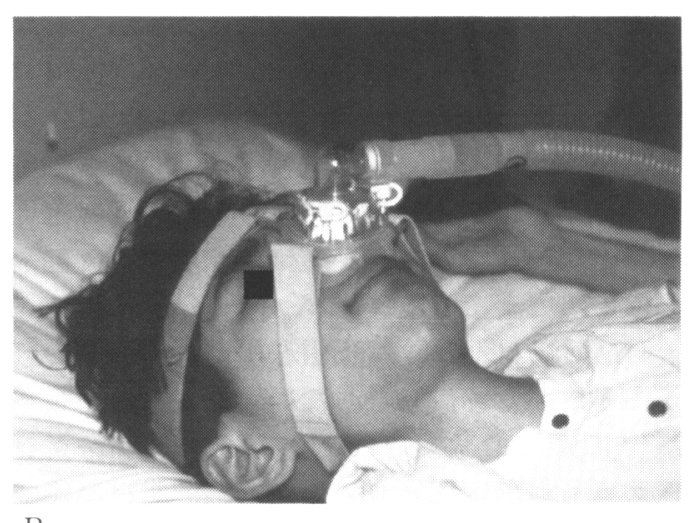

B

図 2 A Sullivan Babble mask

文字どおりマスクが二重になっている。外側 の部分が柔らかく装着感がよく, またエアー リークも少なくなる。

B 同マスクの装着例

写真のようにベルトで固定するが, キャップ 型になったものもある。やはり一人一人の患 者に合わせての工夫が必要である。

4. NPPV の実際一人工呼吸器と患者との インターフェイスー

このインターフェイスこそがNPPVの NPPV たる所以であり，また NPPV を成功さ せるにあたつて最も重要な問題の一つである。 通常鼻マスク (図 2 ) あるいはマウスピースを 用いる。この両者はそれぞれ別個に用いるとい うよりも併用するべきものである。徳島病院で も大多数の患者が覚醒時にはマウスピースを併 用している。

鼻マスクもいくつも種類があるので患者にあ

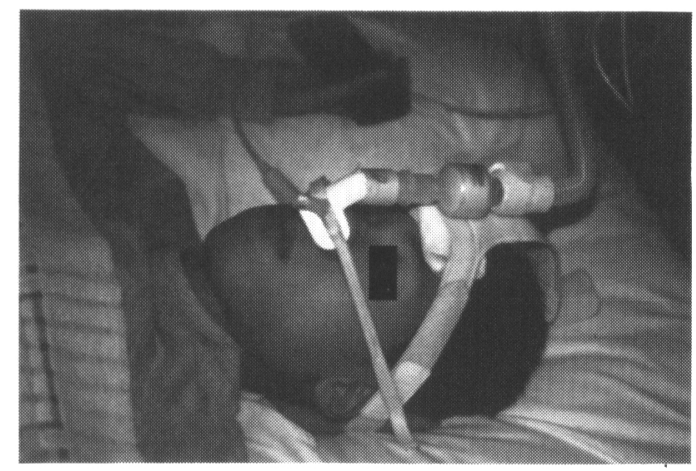

図 3 鼻ピロ (nasal pillows or plugs)

写真はその装着例。この鼻ピロの場合は眼鏡 をかけて使用することもできる。またこの例 では人工鼻も使用している。

わせて使い分ける必要がある。鼻全体を覆う夕 イプのものと鼻孔部のみを覆うもの（鼻ピロ, 図 3 ）に大別することができる。いずれも外国 製であり，日本人用の鼻マスクの開発というこ とも言われているが，筆者はあまりその必要を 感じていない。タイプのみでなくサイズも様久 で幼児用も揃っている。また一人一人の患者に 合わせて作成するキットも売り出されている。

重要なことは一つのマスクに固執させないこ とである。筆者は最低 2 種類のマスクを併用す ることをすすめている。

\section{1. 鼻マスク}

鼻マスクのサイズは死腔の問題からもできる だけ小さいものを選択する方がよい。エアーリ ークはNPSVの場合はあまり神経質になるこ とはないが, 従量式では大きな問題となる。顔 面の形態とマスクの形態がうまく合わないこと があるが，このような時エアーリークを気にす るあまりマスク固定のベルトの締め方にアンバ ランスが生ずると皮膚潰瘍など別の問題がでて くる。筆者の経験ではこれらの点で最も具合の よいのは Sullivan Babble mask (Res Med 社) である。これは顔面に密着するシリコン部分の 取り外しが可能で, マスクの洗浄にも便利であ る。な拖在このマスクの入手に関しては帝人 株式会社在宅医療学術推進本部（ 4002）に直接請求する必要がある。

2. 鼻ピロ (nasal pillows or plugs)

マスクの死腔を最小にするためには直接鼻腔 
に当てる鼻ピロに勝るものはない。これは Adam circuitの商品名でNellcor Puritan Bennett 社から販売されている。同様なものに Monarch Mini Masak (Respironics 社) があ る。鼻ピロが鼻孔に傷などがあると痛みのため 装着が困難であるのに対し, Monarch Mini Masak は鼻孔のみを覆う鼻マスクといったも のなので, 都合がよい。年長児の場合鼻マスク に耐えられなければ鼻ピロがよいとの報告 ${ }^{16)}$ もある。

\section{3.フルフェイスマスク}

鼻, 口の両方を覆い, エアーリークのうち最 も重大な口腔からのリークを防ごうというもの である。当然死腔量は大きくなる。ちょつとし たベルトの締め方のアンバランスが新たなリー クを生み出すことも多く, あまり使い勝手はよ くない。また小児には使用すべきでないとされ ている12)。

\section{4.マウウスピース}

慢性呼吸不全の患者の NPPVでは忘れてな らないのがマウスピースの活用である。徳島病 院でも昼間の NPPVにはほとんどの患者がマ ウスピースを使用しており, 日常生活の QOL を考慮した人工呼吸では欠かせない。通常のマ ウスピースでは睡眠時には使用できないが，べ ルトで固定するSeal Mouthpiece (Nellcor Puritan Bennett 社）も販売されている。

\section{NPPV の評価}

挿管あるいは気管切開法と比べて NPPV は 換気効果という点に関して非常に不確かな方法 である。したがって検查, 評価をくりかえし, 調節する必要がある。特に NPPV 導入初期に は非常に不安定であり, 注意を要する。また睡 眠時には覚醒時とは別の評価が必要である。さ らに睡眠のステージにより変化し，REM 期に は低換気に陷ることがある4,17)。したがって評価 は一点ではなく時系列変化をみて評価すべきだ が，このような点からパルスオキシメトリーが 有用である。筆者は入院患者においては年に 2 〜 6 回睡眠時パルスオキシメトリーを実施して いる。HMVの場合は原則として睡眠時パルス オキシメトリーを月に 1 回実施, その結果によ って血液ガス分析をおこなっている。また
HMVの場合のモニタリングについて Teague $^{12)}$ は少なくとも2〜4 月月毎におこな うべきとしている。その内容として成長, 栄養, 筋力, 呼吸機能, 血液ガス分析などを挙げてい る。

1. パルスオキシメトリー

NPPV 評価に睡眠時パルスオキシメトリー は非常に簡便でかつ有用な検査方法である。 NPPV の場合は覚醒時はまずまずの効果が得 られていても睡眠時には不充分といったことが しばしば見られる。そこで睡眠時のモニタリン グが重要となってくる。最近のパルスオキシメ ータはデータをコンピュータに出力することが 可能なものが多く，このようにして電子化され たデー夕はその利用範囲が大きく広が

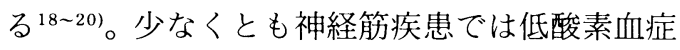
が換気不全によるII型呼吸不全の場合がほとん どで, 二酸化炭素分圧を酸素飽和度でよく回帰 させることができる。

HMVではパソコン通信を用いたデータの転 送も考慮しなくてはならない場合もある。長谷

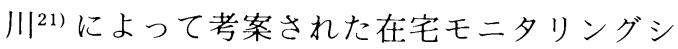
ステムも以前販売されていたが，非常に高額で あったし現在は販売されていない。しかしこの ようなデー夕は既存の商業パソコンネットを利 用しても簡単に転送できる。筆者は HMV 実施 中の患者のデータをNIFTY 経由で転送して もらっている。このシステムはパルスオキシメ 一夕も含めて 20 万以以下で実現できる。

2.カプノメトリー, 経皮的二酸化炭素分圧 測定

有用との成績 ${ }^{22)} も$ あるが筆者の NPPV 実施 者に対する経験ではサンプリングがうまくいか ない。有効なデー夕を得るためには何らかの工 夫が必要であろう。経皮二酸化炭素分圧も有用 であることは間違いないが, 機器が高価でしか も保険で認められていない。

\section{NPPV の実施中の合併症}

当然のことではあるが, NPPV 実施中に発生 する問題はインターフェイスすなわちマスクに 関連するものが多い。これについてもすでに総 説 ${ }^{23,24)}$ にくわしい。ここではさらに筆者の経験 を加えて述べる。 
1.エアーリーク

すでに本文中でも何回かふれたが，この問題 はNPPVの成否のかきとなっていると言って も過言ではない。睡眠中の口腔からのエアーリ 一クは個人差はあるものの NPPV 実施患者の 大多数に認められる ${ }^{25,26)}$ 。 $\mathrm{Hill}^{24)}$ のまとめによ ると程度は様々であるがその頻度は $100 \%$ とあ る。筆者は NPPV を始めた当初どうしてもこ のエアーリークがコントロールできず，やむな く気管切開を実施した例を経験した。しかし現 在ではNPSVに変更することによりほぼ100 \%解决できると考えている ${ }^{11}$ 。

2 . 結膜炎

原因は鼻根部からのエアーリークである。し たがってマスクの装着具合を点検する必要があ る。常におこすようならマスクを交換すること を検討すべきである。

3．マスクの压迫による潰瘍

潰瘍とまでいかなくても圧迫による皮膚損傷 はよくみられる。特に鼻根部に多く認められる。 ベルトの締めすぎ，あるいは締め方のアンバラ ンスが原因となる。場合によっては一時的に鼻 ピロに交換し，回復を待つことも必要となる。

\section{4. 鼻閉，鼻乾燥}

筆者らの経験では，鼻乾燥は NPPV 実施患 者の約 $44 \%$ に認められた。また急性鼻炎による 鼻閉塞は約 $10 \%$ の患者が経験している。 Hill ${ }^{24)}$ のまとめでは25〜 70\%となっている。この問題 は加湿によりほとんど解決できる。加湿にはま ず人工鼻を用いる。ただし NPPVに扔ける人 工鼻使用は保険適応にならない。これは $\mathrm{HMV}$ の際には重要な問題となるのでメーカーとの契 約時によく検討すべきである。人工鼻使用時の 問題点は回路が複雑になり，体動によりマスク のずれ，回路の接続部の外れなどが起こりやす くなることである。鼻閉, 鼻乾燥に対し加湿器 ももちろん有効であるが，そこまで必要となる ことはまずない。ステロイド点鼻も有効である と言われている ${ }^{24)}$ 。鼻炎などによる閉塞の際に は一時的に血管収縮刘の点鼻を抢こなう。

5 . 腹部膨満

腹部膨満は, 筆者等の経験で約 $20 \%$, 前述の 報告では30〜 50\%となっている。この場合，ま ず吸気圧を下げられるかを検討すべきである。
また吸気時間を延長することで解決する場合も ある。

\section{6 . 気胸}

NPPVではまれな合併症であり筆者も経験 がない。この原因はやはり気道内圧上昇である が，気道内圧を必要最小限に抑える努力は常に 必要である。

\section{7. 喀痰排泄困難}

合併症というわけではないが，感染時の気道 分泌物増加または神経筋疾患では原疾患の増悪 による喀痰排泄困難は NPPV 続行に非常に大 きな障害となる。筆者もこのために気管切開を 余儀なくされた症例を経験している。この問題 に対しては用手排痰などの理学療法ではなかな か対応できないことも多い。In-Exsufflator, 別 名 cough machine (Emerson 社, 輸入元：大同 ほくさん）は有効であるが非常に高価である。 特に HMVの場合は導入がほとんど不可能で ある。今後レンタル制度などの対策が必要とな ろう。In-Exsufflator 使用の実際に関しては「神 経筋疾患の呼吸管理」に詳細に述べられている。

\section{7.おわりに}

ここ数年来筋ジストロフィーの人工呼吸にお いてはNPPVが完全に主流となった。また神 経筋疾患のような慢性呼吸不全のみならず急性 呼吸不全に対する応用など，その適応は広がり つつある。しかし厳密な評価のもとに有効と確 認されている疾患は成人の神経筋疾患および胸 壁疾患などその一部に過ぎない27)。神経筋疾患 でも小児例では「有効かもしれない」といった 評価に留まる。小监例においてはすべての疾患 においてまだまだ今後の厳密な評価が必要な段 階であろう。しかし NPPVをまったく無視す ることができないことも事実である。その予後 の評価はもちろんであるが，効果対費用の面か らの検討も必要であろうと考えられている。そ れには症例報告だけではなく，コントロール群 を用いた NPPV の有効性の検討も重要となっ てくるであろう。しかしその対象となる疾患患 者数が少ないこと，コントロール群をおくこと の是非の問題などを考えると，その実施は非常 に困難である。したがって，まず個々の症例の 経験を積み重ね，その情報を報告することが重 
要となるであろう。

\section{教科書的参考文献}

1) Non-invasive respiratory support, ed by Simonds, A.K. Chspmsn \& Hall Medical, London, 1996. 寸評：文字ど拧り NPPVの教 科書. 筆者は英国を中心としたヨーロッパ勢. したがって機種等われわれにはなじみのないも のが多いが，NPPV を実施する際には一読して 打くと非常に参考になる。

2 ) Respiratory Care，1997年 4 月号。才評：本文 でも触れたとおり NPPVの特集号。米国呼吸 ケア協会 (AARC), 米国呼吸ケア基金, Respiratory Care ジャーナルの主催で1996年10月に開 催された NPPV のコンセンサスカンファレン スの報告論文が掲載されている。

3 ) 神経筋疾患の呼吸管理. Bach, J.R., 石川悠加. 日本小児医事出版社, 東京, 1996。 寸評： NPPV に関するアメリカでの第一人者の一人, Bach 先生と日本での第一人者石川先生の共 著. 疾患としては筋ジストロフィー主体に書か れている。また取り扱っている人工呼吸器は RLV-100，BiPAP．実際に NPPV を導入する にあたっての方法が非常に具体的に紹介されて いる。

\section{参考文献}

1) Simonds $\mathrm{AK}:$ Modes of non-invasive ventilatory support. Non-invasive respiratory support ed by Simonds AK, Chspmsn \& Hall Medical, London, 1-6, 1996.

2) Pierson DJ : Noninvasive positive pressure ventilation: History and terminology. Respiratory Care, $43: 370-379,1997$.

3 ）多田羅勝義,富永ユリ, 合田友子・他：Duchenne 型筋ジストロフィ患者に扔ける体外式人工呼吸 器使用時の横隔膜呼吸運動. 日小呼誌, $6: 7-12$, 1995.

4) 多田羅勝義, 西條隆彦, 松岡 優 - 他: 各種人 工呼吸実施の Duchenne 型筋ジストロフィーの 予後一特に人工呼吸下の睡眠時周期性低酸素血 症について一。呼と循, 45：281-285, 1997.

5 ) Sullivan CE, Berthon-Jones M, Issa FG: Remission of severe obesity-hypoventilation syndrome after short-term treatment during sleep with nasal continuous positive airway pressure. Am Rev Respir Dis. 128: 177-181, 1983.

6 ) Bach JR, Alba A, Mosher R, et al. : Intermittent positive pressure ventilation via nasal access in the management of respiratory insufficiency. Chest, $92: 168-170,1987$.

7 ) Ellis ER, Bye PTP, Bruderer JW, et al. :
Treatment of respiratory failure during sleep in patients with neuromuscular disease: Positive-pressure ventilation through nose. Am Rev Respir I)is. 135 : 148-152, 1987.

8 ) Kerby GR, Mayer LS, Pingleton SK : Nocturnal positive pressure ventilation via nasal mask. Am Rev Respir. Dis. 135: 738-740, 1987.

9 ) Segall D: Noninvasive nasal mask-assisted ventilation in respiratory failure of Duchenne muscular dystrophy. Chest. 96:1298-1300, 1988.

10）多田羅勝義，箱原賢司，松岡 優 - 他：閉塞性 睡眠時無呼吸を星した Duchenne 型筋ジストロ フィー患者に対する nasal pressure support ventilation 㙩法。矤療, 51：371-374, 1997.

11）多田羅勝義，箱原篔司，西條隆彦・他：筋ジス トロフィー人㭔吸に扔けるPB335（nasal pressure support ventilation）の有用性. 医療, $51: 417-420,1997$.

12) Teague WG: Pediatric application of noninvasive ventilation. Respiratory Care. 42 : 414-423, 1997.

13) Simonds $A K$ : Equipment. Non-invasive respiratory support ed by Simonds AK, Chspmsn \& Hall Medical, London, 16-37, 1996.

14) Elliott M, Moxham J : Noninvasive mechanical ventilation by nasal or face mask. New York: McCraw-Hill Inc, 1994. (Tobin MJ, ed. Principles and practice of mechanical ventilation)

15) Leger P, Bedicam JM, Cornette A, et al. : Nasal intermittent positive pressure ventila tion. Long-term follow-up in patients with severe chronic respiratory insufficiency. Chest. 105:100 105, 1994.

16) Mayer IS, Kerby (GR, Whitman RA : Evaluation of a new nasal device for administration of continuous positive airway pressure for obstructive sleep apnea (abstract). Am Rev Respir Dis. 139：114, 1989.

17）多田羅勝義，西條隆彦，命助友子・他：人工呼 吸下゙の Duchenne 型筋ジストロフィーにおける ポリソムノグラフィー。医療，50：365-369. 1996.

18）多由羅勝義，中讲健一，水谷 滋：パーソナル コンピュータによる慢性呼吸不全患者のパルス オキシメーターデー夕管理. 医療とコンピュー 夕, $6: 483-487,1994$.

19）多由羅勝義：パーソナルコンピュータとデー夕 変換。小児内科, $27: 9398,1995$.

20）多閺羅勝義：だれでも使えるコンピュー夕表計 算ソフト (2). 小児科診療, 60：863-868, 1997.

21）長谷川久弥：パーソナルコンピュータと在宅モ ニタリング パソコン通仿を朋いた在宅酸素療 
法管理一。览内科, $27: 83$ 87, 1995 .

22）石川悠加, 不川幸底，南 良二：Duchenne 型筋 ジストロフィーの睡眠時無呼吸症候群に対する カプノグラフオキシメーターによる液間モニ夕 リングの有用性. 矤療, 46：398-402, 1992.

23) Simonds AK : Starting nasal intermittent positive pressure ventilation: practical aspects. Non-invasive respiratory support ed by Simonds AK. Chspmsn \& Hall Medical, London, 44 49, 1996.

24) Hill NS : Complications of noninvasive positive pressure ventilation. Respiratory Care. $42: 432442,1997$.
25) Bach JR, Robert D, Leger P, et al. : Sleep fragmentation in kyphoscoliotic individuals with alveolar hypoventilation treated by NIPPV. Chest. 107：1552-1558, 1995.

26) Meyer, TJ, Pressman MR, Benditt J, et al. : Air leaking through the mouth during nocturnal nasal ventilation: effect on sleep quality. Sleep. $20: 561-569,1997$.

27) American Respiratory Care Foundation: Consensus Conference: Noninvasive Positive Pressure Ventilation. Respiratory Care. 42 : 364-369, 1997. 